\title{
Co-existence of physiologically similar sulfate-reducing bacteria in a full-scale sulfidogenic bioreactor fed with a single organic electron donor
}

\author{
Shabir A. Dar • Alfons J. M. Stams • J. Gijs Kuenen • \\ Gerard Muyzer
}

Received: 8 February 2007 /Revised: 21 March 2007 / Accepted: 23 March 2007 / Published online: 14 April 2007

(C) Springer-Verlag 2007

\begin{abstract}
A combination of culture-dependent and independent methods was used to study the co-existence of different sulfate-reducing bacteria (SRB) in an upflow anaerobic sludge bed reactor treating sulfate-rich wastewater. The wastewater was fed with ethanol as an external electron donor. Twenty six strains of SRB were randomly picked and isolated from the highest serial dilution that showed growth (i.e. $10^{8}$ ). Repetitive enterobacterial palindromic polymerase chain reaction and whole cell protein profiling revealed a low genetic diversity, with only two genotypes among the 26 strains obtained in the pure culture. The low genetic diversity suggests the absence of micro-niches within the reactor, which might be due to a low spatial and temporal microheterogeneity. The total 16S rDNA sequencing of two representative strains L3 and L7 indicated a close relatedness to the genus Desulfovibrio. The two strains differed in as many as five physiological traits, which might allow them to occupy distinct niches and thus co-exist within the same habitat. Whole cell hybridisation with fluorescently labeled oligonucleotide probes was performed to characterise the SRB community in the reactor. The isolated strains Desulfovibrio L3 and Desulfovibrio L7 were the most dominant SRB, representing 30-35\% and $25-35 \%$, respectively, of the total SRB community. Desulfobulbus-like bacteria contributed for 20-25\%, and the Desulfobacca acetoxidans-specific probe targeted approximately 15-20\%
\end{abstract}

S. A. Dar · J. G. Kuenen · G. Muyzer $(\bowtie)$

Department of Biotechnology, Delft University of Technology,

Delft, The Netherlands

e-mail: g.muijzer@tudelft.nl

\section{A. J. M. Stams}

Laboratory of Microbiology, Wageningen University,

Wageningen, The Netherlands of the total SRB. The whole cell hybridisation results thus revealed a consortium of four different species of SRB that can be enriched and maintained on a single energy source in a full-scale sulfidogenic reactor.

Keywords Sulfate-reducing bacteria $\cdot$ Microbial ecology . Ecological niches

\section{Introduction}

Many industrial processes, such as metal smelting, flue gas scrubbing and mining generate sulfate-rich wastewater (Lens et al. 1998). These wastewaters usually do not contain any organic carbon, and the addition of external electron donor is required for their treatment. These waste streams cause a range of problems associated with the now well-established anaerobic treatment of these wastewaters, such as a decrease in methane production (Colleran et al. 1995), sulfide toxicity (O'Flaherty and Colleran 2000), foul smell (Lens et al. 2001) and corrosion (Vincke et al. 2001). Of late, bioreactor processes have been developed for treating these sulfate and metal-rich wastewaters. This technology developed by the company Paques BV in The Netherlands (Pol et al. 2001) makes use of the dissimilatory sulfate-reducing capacity of sulfate-reducing bacteria (SRB) to simultaneously remove sulfate and metals in the form of metal sulfides. A typical application is a two-step process that includes dissimilatory sulfate reduction to sulfide (Gibson 1990) as the first step. Subsequently, the sulfide will be bound by heavy metals, such as cobalt, lead, nickel and zinc and precipitated as metal sulfide (Colleran et al. 1995). The second step is the biological oxidation of the remaining sulfide to insoluble elemental sulfur, which is either recovered by sedimentation or a small portion 
converted to $\mathrm{H}_{2} \mathrm{SO}_{4}$ and re-used to neutralise the alkalinity generated because of sulfide production in the first step.

Several full-scale sulfate removal bioreactors are currently in operation. The dominant sulfidogenic communities in these bioreactors are heterotrophic SRB belonging to the family Desulfovibrionaceae (Kaksonen et al. 2004; van Houten et al. 2006). The genus Desulfovibrio represents a phylogenetically coherent group; all species incompletely oxidise lactate to acetate but can utilise hydrogen, formate and ethanol as well (Widdel and Bak 1992).

In an engineered system fed with a single nutritional source and kept under constant operational parameters such as $\mathrm{pH}$, temperature and salinity, competition among species might tend to reduce the species and sub-species diversity according to the principle of competitive exclusion (Gause 1934). However, physiologically competing species can co-exist if they occupy different niches, whereby each species uses distinct parts of the resource base. In the present study, we investigated the co-existence of physiologically similar hydrogenotrophic SRB in a full-scale sulfidogenic bioreactor treating sulfate-rich wastewater using a combination of cultivation and molecular techniques. The reactor was fed with ethanol as carbon and energy source. SRB isolated in pure culture were characterised genetically and physiologically. Micro-diversity among the dominant culturable isolates was assessed by repetitive enterobacterial palindromic polymerase chain reaction (rep-PCR) (Versalovic et al. 1994). Whole-cell hybridisation with fluorescently labelled general and specific probes was used for SRB community characterisation and for the estimation of the relative abundance of the different SRB populations in the reactor.

\section{Materials and methods}

\section{Sludge source}

Granular sludge was obtained from an upflow anaerobic sludge bed (UASB) reactor, treating sulfate-rich wastewater from a chemical plant located in Emmen, The Netherlands. The wastewater fed to the reactor did not contain any organic compound, so ethanol was added as an external electron donor and carbon source. The reactor had a volume of $300 \mathrm{~m}^{3}$ and a feed rate of $60-75 \mathrm{~m}^{3} \mathrm{~h}^{-1}$ The ratio between the amount of electron donor added and the amount of sulfate in the reactor was around $0.4 \mathrm{~kg} / \mathrm{kg}$. Sulfide produced in the reactor was either converted to elemental sulfur through biological sulfide oxidation or precipitated with toxic metals. The reactor was operated at a temperature of $30^{\circ} \mathrm{C}$ and a $\mathrm{pH}$ of $7.0-7.5$. The concentration of sulfate in the wastewater was approximately $1,500 \mathrm{mg} / \mathrm{l}$ and ca. $100 \mathrm{mg} / \mathrm{l}$ in the effluent.
Culture media and isolation of SRB

A basal bicarbonate-buffered and sulfide-reduced medium was used for the enumeration and isolation procedures. The mineral medium contained per litre of distilled water: $0.2 \mathrm{~g}$ $\mathrm{KH}_{2} \mathrm{PO}_{4}, 0.25 \mathrm{~g} \mathrm{NH}_{4} \mathrm{Cl}, 0.5 \mathrm{~g} \mathrm{KCl}, 0.1 \mathrm{~g} \mathrm{CaCl}_{2} \cdot 2 \mathrm{H}_{2} \mathrm{O}, 0.4 \mathrm{~g}$ $\mathrm{MgCl}_{2} \cdot 6 \mathrm{H}_{2} \mathrm{O}, 1.0 \mathrm{~g} \mathrm{NaCl}$ and $0.5 \mathrm{ml}$ of a resazurin solution $\left(0.5 \mathrm{mg} \mathrm{ml}^{-1}\right)$ as a redox indicator. The medium was supplemented with (per litre) the following: $30 \mathrm{ml} 1 \mathrm{M}$ $\mathrm{NaHCO}_{3}$ solution, $1 \mathrm{ml}$ of a vitamin solution, $1 \mathrm{ml}$ of trace element solution with ethylenediamine tetraacetic acid (EDTA; Widdel and Bak 1992) and $0.1 \mathrm{~g}$ of yeast extract. As a reducing agent, $7.5 \mathrm{ml} \mathrm{l}^{-1}$ of $0.2 \mathrm{M} \mathrm{Na}_{2} \mathrm{~S} \cdot 9 \mathrm{H}_{2} 0$ was added. Either lactate or ethanol $(20 \mathrm{mM})$ was used as an electron donor and sulfate $(10 \mathrm{mM})$ as electron acceptor. Enumeration of the potentially dominant heterotrophic sulfate reducers was performed by serial dilutions in Hungate tubes. The Hungate tubes were incubated at $30^{\circ} \mathrm{C}$ in the dark for 7 weeks. The highest positive dilution tubes that showed growth were selected for further isolation. Growth was assayed by measuring sulfide production photometrically (Cord-Ruwisch 1985).

Pure cultures were obtained by repeated transfer in agar shake tubes (Widdel and Pfennig 1984). Purity of the isolates was checked by microscopic observation and further confirmed by denaturing gradient gel electrophoresis (DGGE) analysis of PCR-amplified 16S rRNA gene fragments (Teske et al. 1996).

\section{Phenotypic characterisation}

Substrate utilisation by the isolated strains was determined in duplicate in the same bicarbonate-buffered medium as used for enumeration and isolation but without yeast extract. Growth was tested in 100-ml serum bottles closed with butyl rubber stoppers and aluminium crimp seals. The inoculum size was $1 \%(\mathrm{v} / \mathrm{v})$. The cultures were incubated at $30^{\circ} \mathrm{C}$ for 5 weeks in the dark. Growth was determined by substrate consumption or product formation as well as by checking for increase in optical density at $660 \mathrm{~nm}\left(\mathrm{OD}_{660}\right)$. The following substrates were tested as electron donors in the presence of $10 \mathrm{mM}$ sulfate: $10 \mathrm{mM}$ each of pyruvate, fumarate, butyrate, formate, propanol, ethanol, methanol, serine and cysteine; $5 \mathrm{mM}$ each of malate, glycolate and glycerol; $2.5 \mathrm{mM}$ of benzoate; and $0.5 \%(\mathrm{w} / \mathrm{v})$ of casamino acids. Sulfite, thiosulfate and $2 \%(\mathrm{w} / \mathrm{v})$ elemental sulfur were tested as electron acceptors in the presence of lactate as electron donors.

For measuring catalase activity, the fully grown isolates were centrifuged at $13,000 \times g$. The cell pellets were resuspended on glass slides with a drop of $3 \%(\mathrm{v} / \mathrm{v}) \mathrm{H}_{2} \mathrm{O}_{2}$, bubbles indicated the presence of catalase. Detection of desulfoviridin was performed according to Postgate (1959). 
Gram staining was performed as previously described (Bartholomew 1962).

\section{Analytical methods}

Acetate and other volatile fatty acids were analysed either by gas chromatography (GC) or high performance liquid chromatography (HPLC). For GC, a Chromopack 9001, equipped with a flame ionisation detector and a fused-silica capillary column $15 \times 0.53 \mathrm{~mm}$ HP-Innowax, was used. The column temperature was $120^{\circ} \mathrm{C}$. The temperature of the injector and detector were 180 and $200^{\circ} \mathrm{C}$, respectively. Helium was used as a carrier gas. An Aminex HPX-87H column from Bio-Rad $\left(T=60^{\circ} \mathrm{C}\right)$ coupled to a UV and a RI detector was used for HPLC; phosphoric acid $(0.05 \mathrm{M})$ was used as an eluent. Sulfide was measured quantitatively by a colorimetric assay (Cline 1969).

\section{DNA extraction}

Genomic DNA was isolated from the bacterial cultures using the Ultra Clean Soil DNA extraction kit (MOBIO Laboratories, California) according to the manufacturer's protocol. The quality of the extracted DNA was examined on a $1 \%(\mathrm{w} / \mathrm{v})$ agarose gel and the amount quantified by absorption spectrophotometry using the Nanodrop ND1000 TM (NanoDrop Technologies, Delaware). Extracted DNA was stored at $-20^{\circ} \mathrm{C}$ until subsequent use in different PCR reactions.

\section{PCR amplification and DGGE of 16S rRNA genes}

For DGGE analysis, amplification of partial 16S rRNA gene was carried out using the primers 341F-GC and 907R as described by (Schäfer and Muyzer 2001), while primers GM3 and GM4 (Muyzer et al. 1995) were used to amplify the nearly complete 16S rRNA gene for sequencing and subsequent phylogenetic analysis. PCR amplification and DGGE was performed as described previously (Schäfer and Muyzer 2001). The quality of the PCR products was examined on $1 \%(\mathrm{w} / \mathrm{v})$ agarose gel, and the yield was quantified by absorption spectrophotometry using the Nanodrop ND-1000 TM (NanoDrop Technologies).

DNA sequencing and phylogenetic analysis

The nearly complete 16S rRNA gene fragments, obtained from the strains L3 and L7, were purified using the Qiaquick Gel Extraction Kit (Qiagen, Hilden, Germany). Purified PCR products were sequenced by the company BaseClear (Leiden, The Netherlands). The DNA sequences of about $1,400 \mathrm{bp}$ were first compared to the sequences deposited in public databases using the NCBI
BLAST search tool (http://www.ncbi.nlm.nih.gov/BLAST; McGinnis and Madden 2004). Subsequently, the sequences were imported into the ARB software programme (Ludwig et al. 2004) and aligned using the automatic aligner function. The alignment was further corrected manually, and a phylogenetic tree was constructed using the neighbour-joining algorithm with Felsenstein correction.

\section{rep-PCR fingerprinting}

The genetic diversity of the isolates was analysed by repPCR (Versalovic et al. 1994) using the primer GTG5 (5O'gTggTggTggTggTg-3'). The amplification reaction was performed as previously described (Foti et al. 2006). A 1-kb size marker and $600 \mathrm{ng}$ of the PCR product were loaded onto a $1.5 \%(\mathrm{w} / \mathrm{v})$ agarose gel containing $0.5 \times$ TAE-buffer (200 mM Tris-acetate, $0.5 \mathrm{mM}$ EDTA, $\mathrm{pH}$ 8). The electrophoresis was performed for $14 \mathrm{~h}$ in a cold room at a constant voltage of $65 \mathrm{~V}$. The gel was subsequently stained with ethidium bromide $(0.5 \mu \mathrm{g} / \mathrm{ml})$ and photographed under UV illumination using the GelDoc UV Transilluminator (Bio-Rad, Hercules, CA).

Sodium dodecyl sulfate-polyacrylamide gel electrophoresis analysis

Denaturing sodium dodecyl sulfate-polyacrylamide gel electrophoresis of whole-cell protein (in cell-free extract obtained by sonication) was performed on $12 \%$ polyacrylamide gels according to Laemmli (1970). The gels were stained with Coomassie Brilliant Blue and photographed using visible light.

\section{Design of oligonucleotide probes}

Specific oligonucleotide probes for the 16S rRNA of the two strains were designed using the Probe Design tool of the ARB software package (Ludwig et al. 2004). The requirements for designing the probes included high specificity, with no organism outside the intended target group having 100\% similarity within the target sequence, and the target sequence being located within the high accessibility region of $16 \mathrm{~S}$ rRNA molecule as suggested previously (Behrens et al. 2003). The probes were named with a number that indicates the position of the first base in the target sequence (by Escherichia coli numbering). The oligonucleotides used for in situ hybridisation are given in Table 1 .

Whole cell hybridisation

Cells from strains L3 and L7 and from the original reactor were fixed, washed and spotted onto Teflon-coated multiwell microscopic slides as described previously (Dar et al. 
Table 1 16S rRNA-targeted oligonucleotide probes used in this study

\begin{tabular}{llll}
\hline Probe name $^{\mathrm{a}}$ & Target organisms & Probe sequence $\left(5^{\prime}-3^{\prime}\right)$ & Reference \\
\hline EUB338_I & Most bacteria & GCT GCC TCC CGT AGG AGT & Amann et al. (1990) \\
EUB338_II & Phylum Planctomycetes & GCA GCC ACC CGT AGG TGT & Daims et al. (1999) \\
EUB338_III & Phylum Verrucomicrobia & GCT GCC ACC CGT AGG TGT & Daims et al. (1999) \\
ARCH915 & Archaea & GTG CTC CCC CGC CAA TTC & Stahl and Amann (1991) \\
SRB385 & Most Deltaproteobacteria & CGG CGT CGC TGC GTC AGG & Amann et al. (1990) \\
SRB385Db & Some Deltaproteobacteria & CGG CGT TGC TGC GTC AGG & Rabus et al. (1996) \\
DSR660 & Genus Desulfobulbus & GAA TTC CAC TTT CCC CTC TG & Devereux et al. (1992) \\
DSBA1017 & Desulfobacca acetoxidans & GTT GCC AGG CAC CCC CAT & Dar et al. (2007) \\
DSV119 & Desulfovibrio strain L3 & GGC AGA TCA TCC ACG CGT & This study \\
DSV139 & Desulfovibrio strain L7 & CGC TGT TAT CCC GAT CAC & This study \\
\hline
\end{tabular}

${ }^{a}$ EUB338 is a combination of EUB338_I, EUB338_II and EUB338_III.

2007). Hybridisation was carried out according to the protocol described by Manz et al. (1992) using a formamide concentration of $35 \%(\mathrm{v} / \mathrm{v})$. Quantification of the hybridised cells was performed as described previously (Neef et al. 1996). The hybridised cells were analysed by two independent observers for determining the fraction of positive signal from each probe relative to the signal visualised with general probes for bacteria (EUB338 I, II and III), SRB (SRB385 and SRB385Db) or with the general DNA stain DAPI (4', 6' -diamidino-2-phenylindole). In addition, a general probe specific for members of the domain Archaea (ARCH915) was used. The hybridisation experiments were done in duplicate using different fluorochromes for each probe. Different microscopic fields on each slide were analysed to confirm the results. Hybridisation stringencies of the newly designed probes were determined by performing hybridisations with increasing formamide concentrations as described previously (Manz et al. 1992) using target organism(s) and non-target organism displaying three mismatches within the target region.

Sequence accession numbers

The nearly complete rRNA gene sequences of strains L3 and $\mathrm{L} 7$ have been deposited in GenBank under accession nos. EF055876 and EF055877, respectively.

\section{Results}

Reactor performance

The amount of ethanol dosed to the reactor was continuous and limited to the amount required for sulfate reduction according to the net stoichiometric reaction for sulfidogenic oxidation of ethanol and its major degradation intermediate, acetate. The equations are as follows:

$2 \mathrm{CH}_{3} \mathrm{CH}_{2} \mathrm{OH}+\mathrm{SO}_{4}^{2-} \rightarrow 2 \mathrm{CH}_{3} \mathrm{COO}^{-}+\mathrm{HS}^{-}+\mathrm{H}^{+}+2 \mathrm{H}_{2} \mathrm{O}$

$$
\mathrm{CH}_{3} \mathrm{COO}^{-}+\mathrm{SO}_{4}^{2-} \rightarrow 2 \mathrm{HCO}_{3}^{-}+\mathrm{HS}^{-}
$$

The sulfate removal efficiency at the time of sampling was more than $93 \%$. Less than $1 \mathrm{mg}$ of acetate was estimated in the effluent and no significant biogas $\left(\mathrm{CH}_{4}\right)$ production from the oxidation of organic source was observed at the time of sampling.

\section{Enumeration and isolation of SRB}

The maximum number of culturable SRB observed with lactate or ethanol as substrate in the serial dilution tubes was in the order of $10^{8}$ cells $\mathrm{ml}^{-1}$. The tubes with growth in the highest dilution were used for isolation in agar shake tubes. In total, 26 strains were obtained in pure culture, 17 on lactate and nine on ethanol as substrate. Sub-cultivation of the isolated strains was carried out on lactate. Apart from microscopic observation, the purity of the isolated strains was confirmed by single bands obtained from the DGGE of partial 16S rRNA genes amplified from the strains. The DGGE results of the 26 isolated strains identified two melting types (results not shown).

\section{Genomic fingerprinting}

The isolated strains were subjected to genomic fingerprinting, i.e. rep-PCR, to resolve any higher degree of genetic diversity among the strains. The rep-PCR profiles of the strains (Fig. 1) revealed the presence of two distinct genotypes with no micro-diversity among the strains. Furthermore, the whole 


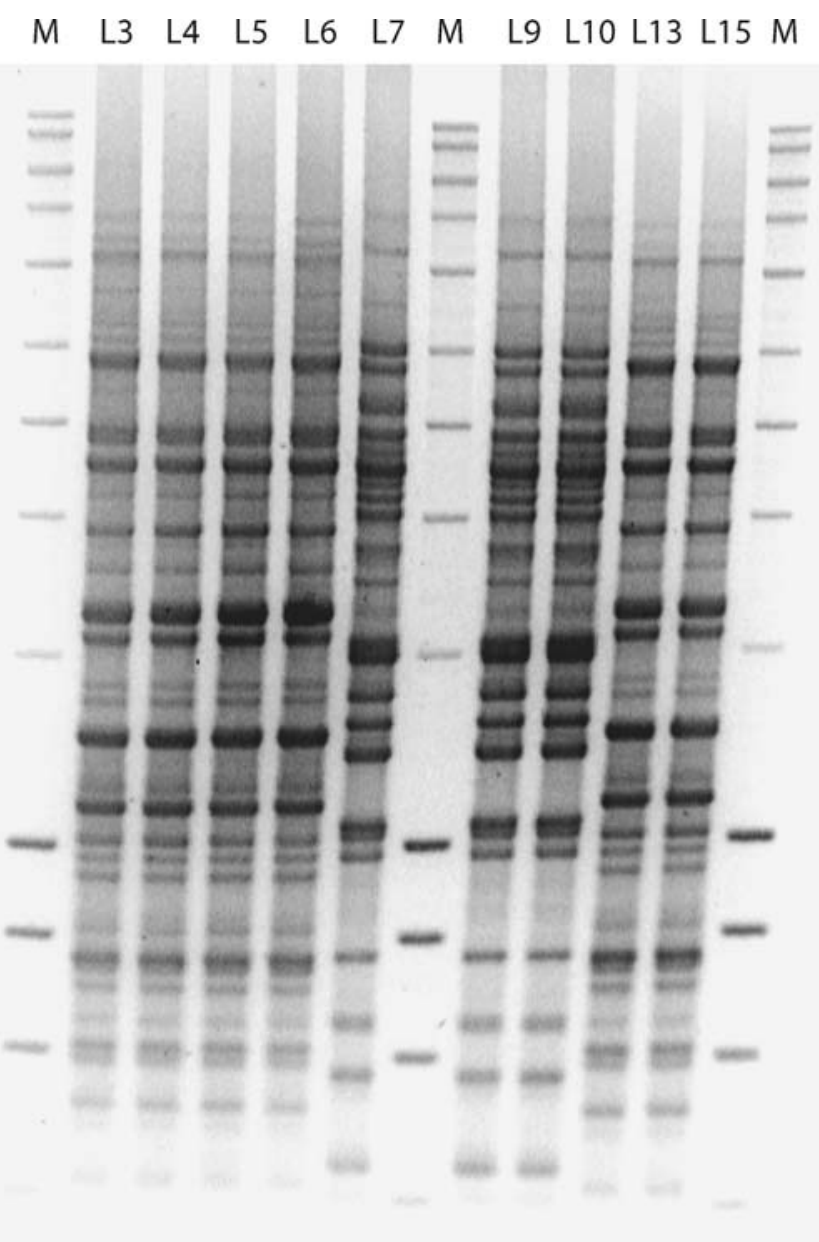

Fig. 1 rep-PCR patterns of different strains isolated from the fullscale sulfidogenic bioreactor. $M$ is the molecular weight marker

cell protein profile of representative strains of the two groups, grown on the same substrate (i.e. lactate and sulfate) and under similar conditions of $\mathrm{pH}$ and temperature, gave only two distinct profiles (Fig. 2), confirming the presence of two genotypes. Two isolates, strain L3 and L7, were chosen

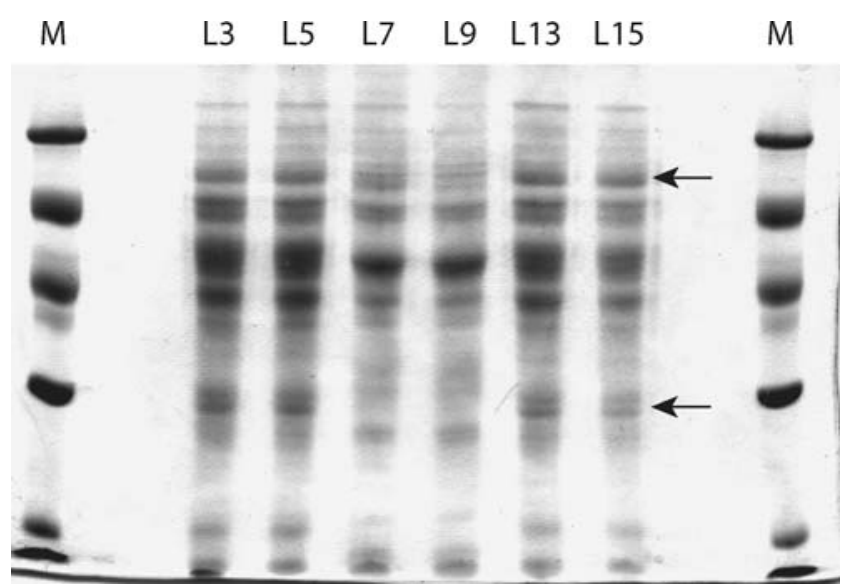

Fig. 2 Whole cell protein profile of different strains isolated from the full-scale sulfidogenic bioreactor. $M$ is the molecular weight marker. The arrows depict protein bands that are expressed in one or the other genotype as representatives of the two genotypes and were subjected to a more detailed phylogenetic and phenotypic analysis.

Phylogenetic analysis

A similarity check using the NCBI BLAST search tool of the nearly complete $16 \mathrm{~S}$ rRNA gene sequences obtained from strain L3 and L7 indicated $98 \%$ sequence similarity to Desulfovibrio strain SB1 and $99 \%$ sequence similarity to Desulfovibrio mexicoense, respectively. The phylogenetic affiliation of the obtained sequences is presented in Fig. 3. A neighbour-joining tree based on nearly complete 16S rRNA gene sequences was generated, confirming the close affiliation of the isolated strains L3 and L7 to Desulfovibrio strain $\mathrm{SB} 1$ and Desulfovibrio mexicoense, respectively.

Phenotypic characterisation of the strains

All isolates had a vibrio to spiral cell morphology. Two distinct groups could be identified based on size and motility. One group of cells related to Desulfovibrio strain SB1 was motile, and their size ranged from $4-7 \mu \mathrm{m}$ in length and $1 \mu \mathrm{m}$ in width. The other group was non-motile, and the size was $1-2 \mu \mathrm{m}$ in length and $0.5 \mu \mathrm{m}$ in width.

Table 2 shows the substrate utilisation patterns of the two isolates. Both strains used lactate, ethanol, pyruvate, glycerol and casamino acids as electron donors. Hydrogen and formate could only be used as substrates in the presence of acetate as carbon source. The organic substrates were incompletely oxidised to acetate. Acetate, propionate, butyrate, glycolate and methanol could not be used as

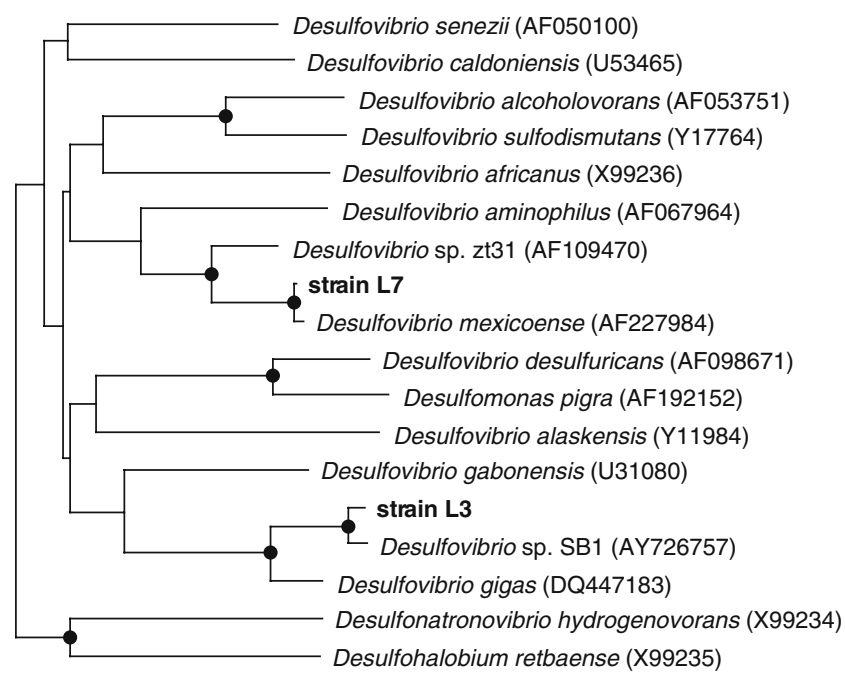

$1 \%$

Fig. 3 Neighbour-joining tree based on nearly complete 16S rRNA gene sequences showing the phylogenetic affiliation of the two isolated SRB, strain L3 and L7. The sequence of Desulfobacter postgatei was used as an outgroup but was pruned from the tree. Dots on the nodes indicate bootstrap values of $90 \%$ or higher $(1,000$ replicates). The bar indicates $1 \%$ sequence difference 
Table 2 Phenotypic characterisation of strains L3 and L7

\begin{tabular}{lll}
\hline Characteristics & Strain L3 & Strain L7 \\
\hline Cell morphology & Vibrio & Vibrio \\
Motility & + & - \\
Desulfoviridin & + & + \\
Catalase & + & + \\
Gram staining & - & - \\
Electron donors & & \\
H$_{2}$ plus acetate & + & + \\
Pyruvate & + & + \\
Lactate & + & + \\
Acetate & - & - \\
Propionate & - & - \\
Fumarate & + & - \\
Butyrate & - & - \\
Formate & + & + \\
Propanol & - & - \\
Ethanol & + & + \\
Methanol & - & - \\
Serine & - & + \\
Cysteine & - & + \\
Malate & + & - \\
Glycolate & - & - \\
Glycerol & + & + \\
Benzoate & - & + \\
Casamino acids & + & + \\
Electron acceptors & + & + \\
Thiosulfate & & + \\
Sulfite & & + \\
Elemental sulfur & & + \\
& & \\
\hline
\end{tabular}

electron donors by both strains. Fumarate and malate were used by strain L3 but not by strain L7, while serine and cysteine were utilised by strain L7 but not by strain L3. Sulfate, thiosulfate and sulfite were used as electron acceptors by both strains. In addition, strain L 7 could also use elemental sulfur as an electron acceptor.

\section{Whole cell hybridisation}

After isolation of the most abundant culturable SRB, whole cell hybridisation with specific oligonucleotide probes was performed to estimate the abundance of strains L3 and L7 in the original sludge sample. The specificity of the designed oligonucleotide probes (DSV119 and DSV139) was verified using growing cells of strain L3 and Desulfovibrio gigas for probe DSV119 and cells of strain L7 and Desulfovibrio mexicoense for probe DSV139. Strain L3 served as a non-target species for L7 and vice versa. A formamide concentration of $35 \%(\mathrm{v} / \mathrm{v})$ was found stringent enough to discriminate between the two strains (Fig. 4a). In addition, probes specific for cells of Desulfobulbus (i.e. DSR660) and Desulfobacca acetoxidans (i.e. DSBA1017), which we had detected previously in a similar sulfidogenic reactor (Dar et al. 2007), were also used.

The relative percentage of cells that hybridised with probe DSV119, which is specific for strain L3, was 30-35\% of the total SRB385-positive cells and 15-20\% of the EUB338positive cells (Table 3; Fig. 4b,c). The probe specific for strain L7, i.e. DSV139, was detected between $25-35 \%$ of the SRB385-positive cell and $10-20 \%$ of the EUB338positive cells (Table 3; Fig. 4b,c). The Desulfobulbus and Desulfobacca-specific probes also gave a positive signal, but these SRB were somewhat less abundant than Desulfovibrio positive cells. The Desulfobulbus-specific probe, DSR660, targeted approximately $20-25 \%$ of the total SRB cells and $10-15 \%$ of the total bacterial cells (Table 3; Fig. 4d). The Desulfobacca acetoxidans-specific probe DSBA1017 targeted approximately $15-20 \%$ of the total SRB cells and $8-10 \%$ of bacterial cells (Table 3; Fig. 4e). The percentage of cells that hybridised with probe specific for Archaea (probe ARCH915) was less than $0.1 \%$ of the total DAPI stained cells (Table 3; Fig. 4f).

\section{Discussion}

Based on the observed sulfate removal efficiency $(>93 \%)$ and the amount of ethanol dosed to the reactor, it may be assumed that a major part of electron flow from the substrate is scavenged by the SRB. The presence of less than a milligram of acetate in the effluent stream with no significant production of $\mathrm{CH}_{4}$ points to the oxidation of ethanol mainly through sulfate reduction, although fermentation of ethanol through acetogenesis cannot be ruled out. The metabolic products of fermentation and acetogenesis, mainly acetate and hydrogen, may serve as substrates for methanogens and sulfate reducers; however, under high sulfate concentrations in the reactor, hydrogen and acetate would be more readily used by hydrogenotrophic and acetate-utilising sulfate reducers, respectively, because of more favourable substrate affinity $\left(\mathrm{K}_{\mathrm{s}}\right)$ values of the SRB for these substrates (Stams et al. 2005). Fermentation of ethanol with propionate as the major reduced end product has also been described in the literature (Schink 1984; Tholozan et al. 1992); and under such fermentation, propionate will serve as an energy source for the members of the genus Desulfobulbus among the SRB.

Genetic diversity among the dominant culturable isolates

Compared to high micro-diversity among phylogenetically similar strains detected in sediments (Sass et al. 1998; Wieringa et al. 2000; Klepac-Ceraj et al. 2004), no such micro-diversity was observed within the 26 strains isolated from the 
Fig. 4 a Mixture of cells of strain L3 and L7 hybridised with probe Dsv139 labelled with Cy5 (blue), probe Dsv119 labelled with $\mathrm{Cy} 3$ (red) and probe SRB385 labelled with Fluos (green). b Sludge sample from a full-scale sulfidogenic bioreactor hybridised with probe Dsv139 labelled with $\mathrm{Cy} 3$ (red), probe Dsv119 labelled with Cy5 (blue) and SRB385 labelled with Fluos (green). c Sludge sample hybridised with probe Dsv139 labelled with Cy5 (blue), probe Dsv119 labelled with Cy3 (red) and EUB338 labelled with Fluos (green). d Sludge sample hybridised with probe DSR660 labelled with Fluos (green), probe SRB385 labelled with Cy3 (red) and EUB338 labelled with Cy5 (blue). e Sludge sample hybridised with probe SRB385 labelled with Fluos (green), probe DSBA1017 labelled with Cy3 (red) and probe EUB338 labelled with Cy5 (blue). f Sludge sample hybridised with probe Arch915 labelled with Fluos (green), probe SRB385 labelled with Cy3 (red) and EUB338 labelled with Cy5 (blue). Bar is $20 \mu \mathrm{m}$
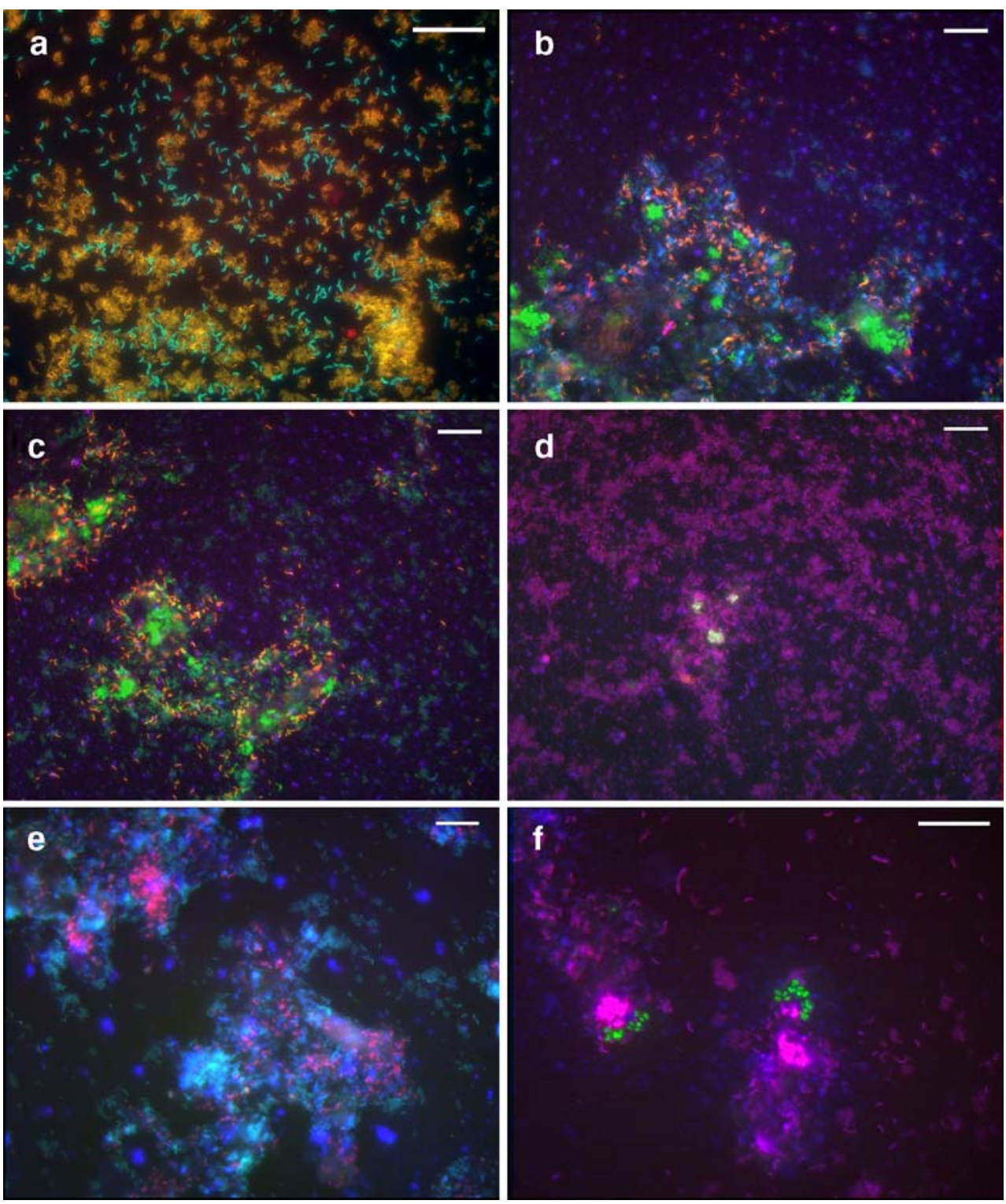

bioreactor. The chemical complexity of sediments with steep gradients of substrate concentrations, redox potential and $\mathrm{pH}$ may give rise to a number of physico-chemical and depthdefined micro-niches, resulting in the evolution of co-existing but genetically distinct sub-populations (Gray et al. 1999). In addition, Torsvik et al. (2002) suggested structural complexity of sediments being an important factor that allows nutritional partitioning, creating numerous niches that, in turn, results in genetic diversification of populations. From the 26 strains isolated, the ones that had identical 16S rRNA gene sequences were also identical by genomic fingerprinting (Fig. 1) and whole cell protein electrophoresis (Fig. 2). Based on the rep- and protein profiles, two genotypes could be identified among the 26 strains isolated. The absence of micro-diversity among the dominant culturable Desulfovibrio populations suggests the existence of a few ecological niches in the reactor. The long-term operation of the reactor under stable operational parameters, like constant temperature, $\mathrm{pH}$, salinity etc., combined with the selection pressure because of nutritional limitation (i.e. the use of a single energy source), might be the reason for absence of micro-diversity. In addition, the upward flow of wastewater through the reactor

Table 3 Relative abundance of SRB and Archaea ${ }^{\mathrm{a}}$

\begin{tabular}{lccc}
\hline Probe & SRB385 & EUB338 & DAPI \\
\hline DSV119 & $30-35$ & $15-20$ & $12-16$ \\
DSV139 & $25-35$ & $10-20$ & $8-16$ \\
DSR660 & $20-25$ & $10-15$ & $8-12$ \\
DSBA1017 & $15-20$ & $8-10$ & $6-8$ \\
ARCH915 & - & - & $<0.1$ \\
\hline
\end{tabular}

${ }^{\text {a }}$ Percentage of positive cells relative to those detected by a mixture of probes SRB385 and SRB385Db (SRB385), a mixture of probes EUB338 I, II and III (EUB338) and to cells stained with the DNA stain DAPI. 
results in frequent mixing, which, in turn, might prevent the creation of micro-habitats that are assumed to be important for the evolution of genetically distinct sub-populations (Torsvik et al. 2002).

Although the viable cell count of SRB observed $\left(10^{8}\right.$ cell $\left.\mathrm{ml}^{-1}\right)$ was comparable to the previous studies (Vester and Ingvorsen 1998; Oude Elferink et al. 1999; Roest et al. 2005; van Houten 2006), it cannot be ruled out that potential biases associated with culture-based enumeration techniques might have underestimated the overall SRB population diversity.

Phenotypic and phylogenetic characterisation of the dominant culturable isolates

The physiological characteristics (Table 2) of strain L3 and L7 indicated that they are sulfate reducers. The two isolates oxidised lactate and ethanol incompletely to acetate in the presence of sulfate as electron acceptor. Both used $\mathrm{H}_{2}$ and formate in the presence of acetate as carbon source. These metabolic traits, in addition to the presence of desulfoviridin and a typical vibrio-shaped morphology, suggested that they are the members of the genus Desulfovibrio (Widdel and Bak 1992). Desulfovibrio are Gram-negative sulfate reducers, most of which oxidise their substrates incompletely to acetate (Widdel and Bak 1992). Previous studies have demonstrated the dominance of Desulfovibrio species in freshwater sediments (Sass et al. 1998), in oil wells (Voordouw et al. 1996) and in several wastewater treatment plants (Santegoeds et al. 1998; Dar et al. 2005). 16S rRNA sequence analysis of the two strains, L3 and L7, confirmed their affiliation to other members of the genus Desulfovibrio (Fig. 3), with Desulfovibrio strain SB1 and Desulfovibrio mexicoense as closest relatives, respectively. Desulfovibrio strain SB1, a mesophilic, Gram-negative SRB was isolated from anaerobic sludge of a gas lift reactor-treating sulfate and zinc-rich wastewater (van Houten 2006); while Desulfovibrio mexicoense was isolated from a UASB digester-treating wastewater from a cheese-manufacturing factory in Mexico (Hernandez-Eugenio et al. 2000).

Co-existing SRB populations in the reactor

After isolation of the most abundant culturable SRB, i.e. the motile strain L3 and non-motile strain L7, whole cell hybridisation using fluorescently labelled oligonucleotide probes was performed to search for their specific signals in the fixed sludge sample. Hybridisation results not only confirmed the presence of the two isolates but also gave an estimate of their abundance relative to the total SRB population and to the overall bacterial community present (Table 3; Fig. 4). Fluorescence in situ hybridisation (FISH) results indicated that the two isolates indeed made up a major part of the hydrogenotrophic SRB community present in the reactor. Cells detected by probe Dsv119, specific for the motile strain L3, appeared as single cells or as chains of three to four cells, while cells detected by probe Dsv139, specific for the non-motile strain L7, appeared as individual cells or as loose aggregates.

According to the ecological principle of competitive exclusion, co-existence of physiologically related populations in the same habitat can be understood if they occupy distinct ecological niches (Gause 1934). Although a number of similarities can be drawn between the strains, L3 and L7, from their substrate utilisation profiles (Table 2), the phenotypic differences together with differences in the range of substrates used by the two isolates may allow them to adapt to slightly different niches within the reactor. The two isolates differed in as many as five physiological properties, which are the use of malate, formate, serine and cysteine as energy sources and sulfur as an electron acceptor (Table 2). The use of elemental sulfur in particular by strain L7 will give it a selective advantage over strain L3 in those places in the reactor where elemental sulfur might be available because of the re-circulation fluid from the aerobic reactor; whereas the motility of strain L3 will confer a competitive advantage to it over strain L7. Potential benefits of motility may include increased efficiency of nutrient acquisition and avoidance of toxic substances (An et al. 2006). The presence of Desulfobulbus-like SRB besides the members of Desulfovibrio in the same habitat could be explained because of the ability of Desulfobulbus to use the fermentation product propionate as an energy source as well; furthermore, under limiting sulfate concentrations, Desulfobulbus competes more successfully for ethanol than other sulfate reducers by its ability to ferment ethanol (Laanbroek et al. 1982). The simultaneous presence of Desulfovibrio and Desulfobulbus in wastewater treatment systems has often been reported in the literature (Nanninga and Gottschal 1987; Raskin et al. 1995; Okabe et al. 2003).

Among the complete oxidisers, the probe specific to Desulfobacca acetoxidans gave a positive signal, suggesting their dominance among the acetotrophic sulfate reducers. Desulfobacca acetoxidans, first isolated from a sulfidogenic bioreactor (Oude Elferink et al. 1999), is a Gram-negative SRB that can utilise acetate as the only source of organic carbon and electron donor. Kaksonen et al. (2004) also found Desulfobacca acetoxidans-like SRB in their lab-scale fluidised-bed reactors that were fed with a single electron donor, i.e. lactate or ethanol.

In summary, this study demonstrated the presence of a consortium of four sulfate-reducing populations in the reactor maintained on a single substrate (ethanol). This is in contrast to the findings of Kaksonen et al. (2004) who reported a relatively more diverse consortium of SRB in a fluidised-bed 
reactor fed with ethanol or lactate as the only energy source, using clone libraries and DGGE as molecular methods for microbial characterisation. The observed difference in the extent of diversity might be due to the difference in the molecular methods employed. The general probes like DSR660, used during FISH analysis, cannot discriminate among the different species, and the probes like DSV119, DSV139 and DSBA1017 target only the specific populations. A likely complete oxidation of ethanol through sulfate reduction might thus be assumed to be taking place through a combined effort of hydrogenotrophic sulfate reducers (i.e. the motile strain L3, the non-motile strain L7 and Desulfobulbus spp.) oxidising ethanol incompletely to acetate and Desulfobacca acetoxidans oxidising acetate completely to $\mathrm{CO}_{2}$. Genetic diversity analysis of the most dominant culturable Desulfovibrio populations suggests that long-term stable operation of a reactor with constant operational parameters and frequent mixing might result in the absence of microdiversity.

Acknowledgement We thank the Dutch Science Foundation (NWO) for financial support. Mirjam Foti was thanked for her help with the rep-PCR, Udo van Dongen for his help with FISH and Dimitri Sorokin for the helpful discussion. We thank Dries Buitenwerf of the EMMTEC services BV for providing reactor samples.

\section{References}

Amann RI, Binder BJ, Olson RJ, Chisholm SW, Devereux R, Stahl DA (1990) Combination of 16S rRNA-targeted oligonucleotide probes with flow cytometry for analyzing mixed microbial populations. Appl Environ Microbiol 56:1919-1925

An D, Danhorn T, Fuqua C, Parsek MR (2006) Quorum sensing and motility mediate interactions between Pseudomonas aeruginosa and Agrobacterium tumefaciens in biofilm cocultures. Proc Natl Acad Sci USA 103:3828-3833

Bartholomew JW (1962) Variables influencing results, and the precise definition of steps in gram staining as a means of standardizing the results obtained. Stain Technol 37:139-155

Behrens S et al (2003) In situ accessibility of small-subunit rRNA of members of the domains Bacteria, Archaea, and Eucarya to Cy3labeled oligonucleotide probes. Appl Environ Microbiol 69:1748-1758

Cline JD (1969) Spectrophotometric determination of hydrogen sulfide in natural waters. Limnol Oceanogr 14:454-458

Colleran E, Finnegan S, Lens P (1995) Anaerobic treatment of sulphatecontaining waste streams. Antonie Van Leeuwenhoek 67:29-46

Cord-Ruwisch R (1985) A quick method for the determination of dissolved and precipitated sulfides in cultures of sulfate-reducing bacteria. J Microbiol Methods 4:33-36

Daims H, Bruhl A, Amann R, Schleifer KH, Wagner M (1999) The domain-specific probe EUB338 is insufficient for the detection of all bacteria: development and evaluation of a more comprehensive probe set. Syst Appl Microbiol 22:434-444

Dar SA, Kuenen JG, Muyzer G (2005) Nested PCR-denaturing gradient gel electrophoresis approach to determine the diversity of sulfate-reducing bacteria in complex microbial communities. Appl Environ Microbiol 71:2325-2330
Dar SA, Yao L, van Dongen U, Kuenen JG, Muyzer G (2007) Analysis of diversity and activity of sulfate reducing bacterial communities in sulfidogenic bioreactors using 16S rRNA and $d s r B$ genes as molecular markers. Appl Environ Microbiol 73:594-604

Devereux R, Kane MD, Winfrey J, Stahl DA (1992) Genus- and group-specific hybridization probes for determinative and environmental studies of sulfate-reducing bacteria. Syst Appl Microbiol 15:601-609

Foti M, Ma S, Sorokin DY, Rademaker JLW, Kuenen JG, Muyzer G (2006) Genetic diversity and biogeography of haloalkaliphilic sulfur-oxidizing bacteria belonging to the genus Thioalkalivibrio. FEMS Microbiol Ecol 56:95-101

Gause GF (1934) The struggle for existence. Williams \& Wilkins, Baltimore, MD

Gibson GR (1990) Physiology and ecology of the sulphate-reducing bacteria. J Appl Bacteriol 69:769-797

Gray ND, Howarth R, Rowan A, Pickup RW, Jones JG, Head IM (1999) Natural communities of Achromatium oxaliferum comprise genetically, morphologically, and ecologically distinct subpopulations. Appl Environ Microbiol 65:5089-5099

Hernandez-Eugenio G, Fardeau M, Patel BKC, Macarie H, Garcia J, Ollivier B (2000) Desulfovibrio mexicanus sp. nov., a sulfatereducing bacterium isolated from an upflow anaerobic sludge blanket (UASB) reactor treating cheese wastewaters. Anaerobe 6:305-312

Kaksonen AH, Plumb JJ, Franzmann PD, Puhakka JA (2004) Simple organic electron donors support diverse sulfate-reducing communities in fluidized-bed reactors treating acidic metal- and sulfatecontaining wastewater. FEMS Microbiol Ecol 47:279-289

Klepac-Ceraj V, Bahr M, Crump BC, Teske AP, Hobbie JE, Polz MF (2004) High overall diversity and dominance of microdiverse relationships in salt marsh sulphate-reducing bacteria. Environ Microbiol 6:686-698

Laanbroek HJ, Abee T, Voogd IL (1982) Alcohol conversions by Desulfobulbus propionicus Lindhorst in the presence and absence of sulfate and hydrogen. Arch Microbiol 133:178-184

Laemmli UK (1970) Cleavage of structural proteins during the assembly of the head of the bacteriophage T4. Nature 227:680-685

Lens PNL, Visser A, Janssen AJH, L. Hulshoff Pol L, Lettinga G (1998) Biotechnological treatment of sulfate-rich wastewaters. Crit Rev Environ Sci Technol 28:41-88

Lens P, Boncz M, Sipma J, Brunning H, Rulkens W (2001) Catalytical oxidation of odourous compounds. In: Stuetz R, Frechen F-B (eds) Wastewater treatment odor abatement. International Water Association, London

Ludwig W et al (2004) ARB: a software environment for sequence data. Nucleic Acids Res 32:1363-1371

Manz W, Amann R, Ludwig W, Wagner M, Schleifer K-H (1992) Phylogenetic oligodeoxynucleotide probes for the major subclasses of proteobacteria: problems and solutions. Syst Appl Microbiol 15:593-600

McGinnis S, Madden TL (2004) BLAST: at the core of a powerful and diverse set of sequence analysis tools. Nucleic Acids Res 32:20-25

Muyzer G, Teske A, Wirsen CO, Jannasch HW (1995) Phylogenetic relationships of Thiomicrospira species and their identification in deep-sea hydrothermal vent samples by denaturing gradient gel electrophoresis of $16 \mathrm{~S}$ rDNA fragments. Arch Microbiol 164:165-172

Nanninga HJ, Gottschal JC (1987) Properties of Desulfovibrio carbinolicus sp. nov. and other sulfate-reducing bacteria isolated from an anaerobic-purification plant. Appl Environ Microbiol 53:802-809

Neef A, Zaglauer A, Meier H, Amann R, Lemmer H, Schleifer KH (1996) Population analysis in a denitrifying sand filter: conventional and in situ identification of Paracoccus spp. in methanolfed biofilms. Appl Environ Microbiol 62:4329-4339 
O'Flaherty V, Colleran E (2000) Sulfur problems in anaerobic digestion. In: Lens PNL, Hulshoff Pol L (eds) Environmental technologies to treat sulfur pollution: principles and engineering. International Water Association, London

Okabe S, Ito T, Satoh H (2003) Sulfate-reducing bacterial community structure and their contribution to carbon mineralization in a wastewater biofilm growing under microaerophilic conditions. Appl Microbiol Biotechnol 63:322-334

Oude Elferink SJ, Akkermans-van Vliet WM, Bogte JJ, Stams AJ (1999) Desulfobacca acetoxidans gen. nov., sp. nov., a novel acetate-degrading sulfate reducer isolated from sulfidogenic granular sludge. Int J Syst Bacteriol 49:345-350

Pol LW, Lens PN, Weijma J, Stams AJ (2001) New developments in reactor and process technology for sulfate reduction. Water Sci Technol 44:67-76

Postgate J (1959) A diagnostic reaction of Desulfovibrio desulfuricans. Nature 183:481-482

Rabus R, Fukui M, Wilkes H, Widdle F (1996) Degradative capacities and 16S rRNA-targeted whole-cell hybridization of sulfate-reducing bacteria in an anaerobic enrichment culture utilizing alkylbenzenes from crude oil. Appl Environ Microbiol 62:3605-3613

Raskin L, Zheng D, Griffin ME, Stroot PG, Misra P (1995) Characterization of microbial communities in anaerobic bioreactors using molecular probes. Antonie Van Leeuwenhoek 68:297-308

Roest K, Heilig HG, Smidt H, de Vos WM, Stams AJ, Akkermans AD (2005) Community analysis of a full-scale anaerobic bioreactor treating paper mill wastewater. Syst Appl Microbiol 28:175-185

Santegoeds CM, Ferdelman TG, Muyzer G, de Beer D (1998) Structural and functional dynamics of sulfate-reducing populations in bacterial biofilms. Appl Environ Microbiol 64:3731-3739

Sass H, Wieringa EBA, Cypionka H, Babenzien HD, Overmann J (1998) High genetic and physiological diversity of sulfatereducing bacteria isolated from an oligotrophic lake sediment. Arch Microbiol 170:243-251

Schäfer H, Muyzer G (2001) Denaturing gradient gel electrophoresis in marine microbial ecology. In: Paul JH (ed) Methods in microbiology. Academic, New York

Schink B (1984) Fermentation of 2,3-butanediol by Pelobacter carbinolicus sp. nov. and Pelobacter propionicus sp. nov. and evidence for propionate formation from $\mathrm{C}_{2}$ compounds. Arch Microbiol 137:33-41

Stahl DA, Amann R (1991) Development and application of nucleic acid probes. In: Stackebrandt E, Goodfellow M (eds) Nucleic acid techniques in bacterial systematics. Wiley, Chichester, England, pp 205-248
Stams AJM et al (2005) Metabolic interactions in methanogenic and sulfate reducing bacteria. Water Sci Technol 52:13-20

Teske A, Sigalevich P, Cohen Y, Muyzer G (1996) Molecular identification of bacteria from a coculture by denaturing gradient gel electrophoresis of 16S ribosomal DNA fragments as a tool for isolation in pure cultures. Appl Environ Microbiol 62:4210-4215

Tholozan JL, Touzel JP, Samain E, Grivet JP, Prensier G, Albagnac G (1992) Clostridium neopropionicum sp. nov., a strict anaerobic bacterium fermenting ethanol to propionate through acrylate pathway. Arch Microbiol 157:249-257

Torsvik V, Ovreas L, Thingstad TF (2002) Prokaryotic diversitymagnitude, dynamics, and controlling factors. Science 296:1064-1066

van Houten BHGW (2006) Microbial aspects of synthesis gas fed bioreactors treating metal and sulfate rich wastewaters. Dissertation, Wageningen Agricultural University, Wageningen

van Houten BH, Roest K, Tzeneva VA, Dijkman H, Smidt H, Stams AJ (2006) Occurrence of methanogenesis during start-up of a full-scale synthesis gas-fed reactor treating sulfate and metal-rich wastewater. Water Res 40:553-560

Versalovic J, de Bruijn FJ, Lupski JR (1994) Genomic fingerprinting of bacteria using repetitive sequence based PCR (rep-PCR). Methods Cell Mol Biol 5:25-40

Vester F, Ingvorsen K (1998) Improved most-probable-number method to detect sulfate-reducing bacteria with natural media and a radiotracer. Appl Environ Microbiol 64:1700-1707

Vincke E, Boon N, Verstraete W (2001) Analysis of the microbial communities on corroded sewer pipes-case study. Appl Microbiol Biotechnol 57:776-785

Voordouw G et al (1996) Characterization of 16S rRNA genes from oil field microbial communities indicates the presence of a variety of sulfate-reducing, fermentative, and sulfide-oxidizing bacteria. Appl Environ Microbiol 62:1623-1629

Widdel F, Bak F (1992) Gram-negative mesophilic sulfate-reducing bacteria. In: Balows A, Trüper HG, Dworkin M, Harder W, Schleifer K-H (eds) The prokaryotes, 2nd edn. Springer, Berlin Heidelberg New York, pp 3352-3378

Widdel F, Pfennig N (1984) Dissimilatory sulfate-or sulfur-reducing bacteria. In: Krieg NR, Holt JG (eds) Bergey's manual of systematic bacteriology. Williams \& Wilkins, Baltimore, pp 663-679

Wieringa EB, Overmann J, Cypionka H (2000) Detection of abundant sulphate-reducing bacteria in marine oxic sediment layers by a combined cultivation and molecular approach. Environ Microbiol $2: 417-427$ 